\title{
Call for papers - thematic issue Competences in Environmental Education (EE) and Education for Sustainable Development (ESD)
}

\section{Jana Dlouhá}

Envigogika 9 (1) - Information/ Informace

Published/ Publikováno 31. 5. 2014

DOI: $\underline{10.14712 / 18023061.442}$

\section{Výzva k zasílání příspěvků pro tematické číslo Envigogiky o} Environmentálním vzdělávání a (EV) a Vzdělávání pro udržitelný rozvoj

Competences have been identified as legitimate educational goals wherever it is not only knowledge that counts in learning (and educators are concerned with not only the cognitive domain in their teaching). There is an ongoing discussion on "key competences for all" identified by the European Parliament as a necessary prerequisite for personal fulfilment, active citizenship, social cohesion and employability in a knowledge society (cf. $E P, 2006)$. Also in the field of EE and ESD, there have been attempts to find appropriate operationalisation of action-oriented, learner-centred, and socially and environmentally responsible educational strategies which would help to realize a transition of the whole education system towards sustainability. Competences appear to be an appropriate concept providing an opportunity especially for a change of traditional teaching/learning practices and proper assessment of these innovations at the level of the student, educational module or programme, and also the policy level - they might be specifically designed for different disciplinary and cultural contexts and easily adjusted for all ISCED levels. As a proper tool for setting transformative educational goals and reflection of the prerequisites/outcomes of the relevant learning processes, they have been stressed in prominent ESD policy documents (UNECE, 2011, 2013), in theoretical discussions (Wiek et al.,2011) as well as in practice (growing knowledge base of case studies in relevant journals).

We encourage concerned experts to enrich this debate and contribute to the pool of knowledge by providing results of their original research and share their experience with practical implementation of the concept - and submit their work for the thematic issue of Envigogika. We accept articles in the category of research papers and case studies; moreover, there is a possibility to provide multimedia presentations of existing learning programmes and other activities. The deadline for submission of the manuscripts is 15 September 2014; the thematic issue will appear after the review process by the end of the year.

The theme of the Envigogika issue is closely related to the international COPERNICUS Alliance Conference to be held on 3 October 2014 the outcomes of which are expected to be one of the main contributions to the UNESCO Decade for ESD (2005-2014), ending this year. Conference-related themes cover curricular aspects of university education; thus they provide an opportunity to reflect ESD-oriented higher education in all disciplinary fields from the perspective of the educator and his/her professional development. Articles related to the themes of the Conference can be presented in parallel sessions as part of the afternoon programme (see here) if they are submitted in the form 
of abstracts through the registration system on the conference website by $15^{\text {th }}$ July 2014 . Other competence-related themes may be submitted for the special issue of Envigogika as well.

Authors are warmly welcome to attend the COPERNICUS Alliance Conference to meet top European experts in the field and discuss issues of common interest. The Conference is closely associated with the UE4SD project which links the competence theme with professional development of university educators in the field of ESD. In the project, 55 partners from 33 countries are represented, the majority of which are expected to attend the Conference as it is a constitutive part of their cooperation. Four regions (East, West, North and South) are evenly covered by the partners' consortium and thus the Conference will be a unique opportunity to also make links with these regional networks. Authors from the Czech Republic and its neighbours are therefore especially encouraged to consider their involvement in the Conference programme as the transition towards sustainability is an issue to be highlighted in this part of the world.

\section{References}

- EP, (2006). Recommendation of the European Parliament and of the Council of 18 December 2006 on key competences for lifelong learning. European Reference Framework in the EC. Official Journal L 394 of 30.12.2006. [online] [cit 2014-0512] available from

http://www.cmepius.si/files/cmepius/userfiles/grundtvig/gradivo/key_competencie s 2006 en.pdf (see also

http://europa.eu/legislation summaries/education training youth/lifelong learnin $\mathrm{g} / \mathrm{c} 11090$ en.htm ).

- UN ECE (2011). Learning for the future: Competences in Education for Sustainable Development. Geneva: United Nations Economic Commission for Europe, Steering Committee on Education for Sustainable Development. Retrieved from http://www.unece.org/fileadmin/DAM/env/esd/ESD Publications/Competences Pu blication.pdf

- UN ECE (2013). Empowering educators for a sustainable future: Tools for policy and practice workshops on education for sustainable development Competences. Geneva: , United Nations Economic Commission for Europe, Steering Committee on Education for Sustainable Development. Retrieved from http://www.unece.org/fileadmin/DAM/env/esd/8thMeetSC/ece.cep.ac.13.2013.4e. pdf

- Wiek, A., Withycombe, L., \& Redman, C. L. (2011). Key competencies in sustainability: a reference framework for academic program development. Sustain Sci, 6(2), 203-218. Retrieved from http://link.springer.com/10.1007/s11625-0110132-6 http://dx.doi.org/10.1007/s11625-011-0132-6 